\title{
Variability of some Important Soil Chemical Properties of Rainfed Low Land Paddy Fields and its Effect on Land Suitability for Rice Cultivation
}

\author{
W.M.U.K. Rathnayake*, R.P. De Silva ${ }^{1}$ and N.D.K. Dayawansa ${ }^{1}$ \\ Postgraduate Institute of Agriculture \\ University of Peradeniya, \\ Sri Lanka
}

\begin{abstract}
ABSTRCT: Available soil-phosphorus (P), exchangeable soil-potassium (K), soil pH and soil Electrical Conductivity (EC) affect rice production and are highly variable in nature mainly due to the variability in water availability. Therefore, experiments were conducted to find out the variability of some important soil chemical properties of rainfed lowland paddy fields and their effect on land suitability for rice cultivation in the Dry (Mahananeriya), Intermediate (Ibbagamuwa) and Wet (Alawwa) regions in the Kurunegala District of Sri Lanka. Randomly collected soil samples from the above three areas were analyzed for available soil-P, exchangeable soil-K, soil $\mathrm{pH}(1: 2.5)$ and EC (1:5). Thematic maps for each parameter were prepared using Inverse Distance Weighted interpolation technique. Weighted sum technique was used to overlay maps to prepare the suitability map as Marginally Suitable, Moderately Suitable, Suitable and Highly Suitable. Results showed that the available soil-P and EC levels are preferable for rice cultivation in the rainfed lowland paddy fields in all three regions. Even with this situation, the potential productivity of the lands cannot be obtained due to variability of soil $\mathrm{pH}$ and exchangeable Potassium contents. Soil $\mathrm{pH}$ and the exchangeable soil Potassium in all rainfed paddy areas of Alawwa is far below the optimum levels for paddy cultivation. In terms of these soil chemical properties, $42 \%$ and $32 \%$ of rainfed paddy fields in Ibbagamuwa and Mahananeriya regions, respectively, are either highly suitable or suitable but $79 \%$ land extent of the rainfed paddy in Alawwa is marginally suitable for rice cultivation. Therefore, a blanket recommendation of remedial measures cannot be introduced to improve productivity of the rainfed paddy fields in these regions while site-specific remedial measures would help to overcome the problems of specific soil chemical properties.
\end{abstract}

Keywords: Lowland paddy, rainfed cultivation, soil chemical properties, suitability

\section{INTRODUCTION}

Almost all paddy fields in Sri Lanka are cultivated with high yielding rice varieties (HYVs). The HYVs need high rate of nutrient supply to produce optimum yield benefits (Abeysiriwardene and Sandanayake, 2000). Therefore, factors that reduce nutrient availability and absorption will adversely affect rice production. Phosphorus (P) and potassium (K) are two major nutrients required by rice and $6 \mathrm{t} / \mathrm{ha}$ of grain yield removes around $20 \mathrm{~kg}$ of $\mathrm{P}$ and $100 \mathrm{~kg}$ of $\mathrm{K}$ per season (Wickramasinghe et al., 2009). The available

\footnotetext{
1 Department of Agricultural Engeneering, University of, Peradeniya, Sri Lanka

Corresponding author: upulr@yahoo.co.uk
} 
soil-Phosphorus (P), exchangeable soil-Potassium (K), soil $\mathrm{pH}$ and soil Electrical Conductivity (EC) are some of the important soil chemical properties that affect rice production. These chemical properties are highly variable in nature mainly due to variability in water availability.

Kurunegala District is one of the major rice-growing districts in Sri Lanka and it occupies $13 \%$ and $8 \%$ of the total paddy extent in the country in Yala and Maha seasons, respectively. In the district, the total rice cultivated extent in the Yala season is 47,666 ha and in Maha season is 74,879 ha (CBSL, 2010). Almost all the area comes under low country (less than $300 \mathrm{~m}$ in elevation) and categorized into nine agro-ecological regions viz. DL1b, IL3, IL1b, IL1a, IM3b, WM3b, WM3a, WL2b and WL3 (Punyawardana et al., 2003). Rice cultivation is done under major and minor irrigation and under rainfed conditions. The rainfed cultivation is predominant in the study area with a cultivated extent of 28,442 ha in Maha season and 17,676 ha in Yala season. The average grain yield in rainfed Maha is $3.5 \mathrm{t} / \mathrm{ha}$ that of Yala is $3.1 \mathrm{t} / \mathrm{ha}$ (CBSL, 2010). These yield levels are well below the average yield recorded for minor irrigation (3.7 t/ha in Maha and 3.3 in Yala) and for major irrigation conditions (4.4 t/ha and $3.6 \mathrm{t} / \mathrm{ha}$ ) (CBSL, 2010). Although there is no water shortage in the Maha season, statistics show that yields are still low in rainfed paddy cultivation. This shows that there are some other reasons causing lower yields. According to Wickramasinghe et al. (2009) differences of soil chemical properties such as available-P, exchangeable-K, soil pH and EC have major influence on rice yield differences.

This study was conducted to find out the variability of some important soil chemical properties of rainfed lowland paddy fields in three climatic zones in the Kurunegala District of Sri Lanka and its' effect on land suitability for rice cultivation.

\section{METHODOLOGY}

\section{Preparation of study sites}

Three agrarian service centre (ASC) areas namely, Mahananeriya, Ibbagamuwa and Alawwa in the Kurunegala District of Sri Lanka representing Dry (DL1b), Intermediate (IL1a) and Wet (WL3) Zone, respectively, were selected as the study sites (Fig. 1). A 1:10000 analogue and digital maps of the Kurunegala District prepared by the Survey Department of Sri Lanka were used to extract and map the paddy areas using Geographic Information System (GIS). Rainfed paddy areas were identified using field survey data. Finally, rainfed paddy areas were extracted for Mahananeriya, Ibbagamuwa and Alawwa ASCs with the help of GIS technology.

\section{Collection and analysis of soil samples}

Soil samples were collected randomly to represent the total rainfed paddy cultivated area of all three ASC regions. Accordingly, 136 samples from Mahananeriya, 257 from Ibbagamuwa and 466 from Alawwa were collected. Sampling locations were geo-referenced with Global Positioning System (GPS). Soil samples were taken up to $15 \mathrm{~cm}$ depth, made into composite samples, processed and sieved through $2 \mathrm{~mm}$ sieve for analysis. The samples were analyzed for available-P by Olsen $\mathrm{P}$ method and exchangeable- $\mathrm{K}$ by $1 \mathrm{~N} \mathrm{NH}_{4} \mathrm{OAc}(\mathrm{pH} 7)$ extraction method, soil pH (1 soil: 2.5 water) and Electrical Conductivity (1 soil: 5 water). Data were tabulated in excel Windows 7 and used for map preparation. 


\section{Preparation of thematic maps}

Thematic maps of available-P, exchangeable-K, soil $\mathrm{pH}$ and EC were prepared for Mahananeriya, Ibbagamuwa and Alawwa ASCs using GIS. The Inverse Distance Weighted (IDW) interpolation technique was used in this study as it produced relatively reasonable results with $81 \%$ accuracy. During the map preparation, soil chemical properties were grouped into classes and class values were assigned to each soil parameter considering their requirements for rice cultivation and data availability. According to the test values reported by the Soil Test based Fertilizer Recommendation Manual of the Department of Agriculture (DOA, 1997) three categories were assigned for available-P i.e. less than $5 \mathrm{mg} \mathrm{P} / \mathrm{kg}, 5-10 \mathrm{mg}$ $\mathrm{P} / \mathrm{kg}$ and more than $10 \mathrm{mg} \mathrm{P} / \mathrm{kg}$, four categories were identified for exchangeable-K, i.e. less than $40 \mathrm{mg} \mathrm{K} / \mathrm{kg}, 40-80 \mathrm{mg} \mathrm{K} / \mathrm{kg}, 80-160 \mathrm{mg} \mathrm{K} / \mathrm{kg}$ and more than $160 \mathrm{mg} \mathrm{K} / \mathrm{kg}$. Soil pH values were groups into five categories as less than 4, 4-5, 5-6, 6-7 and 7-8. EC values were grouped into three as less than $0.15 \mathrm{dS} / \mathrm{m}, 0.15-0.4 \mathrm{dS} / \mathrm{m}$, and 0.4-0.8 dS/m (Lathiff, 2007).

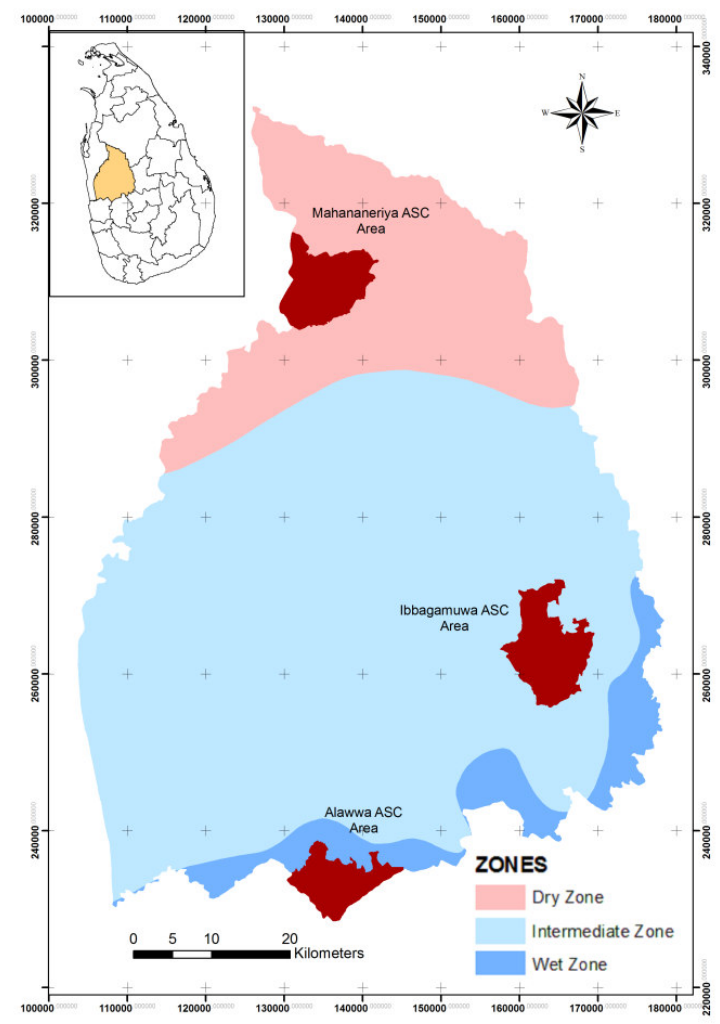

Fig. 1. Map of the study areas: Mahananeriya (DZ), Ibbagamuwa (IZ) and Alawwa (WZ) in Kurunegala district

\section{Assessment of soil suitability}

Prepared thematic maps of available-P, exchangeable-K, soil $\mathrm{pH}$ and EC were overlaid separately for three ASCs. Ratings were given for each category of nutrients based on their suitability. The highest value was awarded for the optimum range of each soil chemical 
parameter (5-10 mg P/kg of available P, 80-160 mg K/ $\mathrm{kg}$ of exchangeable $\mathrm{K}$, 6-7 of soil $\mathrm{pH}$ and less than $0.15 \mathrm{dS} / \mathrm{m}$ of EC) and others were ranked accordingly (Bandara et al., 2005). Then the maps of available-P and exchangeable-K were overlaid using weighted sum technique by giving equal weights for both parameters as both available-P and exchangeable$\mathrm{K}$ are equally important for rice cultivation. Thereafter, $\mathrm{pH}$ and $\mathrm{EC}$ maps were overlaid with the same technique giving weights as 0.75 and 0.25 , respectively, because of the level of importance. Resultant maps of the two overlaid maps were used to prepare the suitability map giving weights as 0.75 (overlaid map of $\mathrm{pH}$ and $\mathrm{EC}$ ) and 0.25 (overlaid map of $\mathrm{P}$ and $\mathrm{K}$ ) in weighted sum technique. Values were reclassified as Marginally Suitable, Moderately Suitable, Suitable and Highly Suitable to prepare the soil suitability map in terms of soil chemical parameters.

\section{RESULTS AND DISCUSSION}

The paddy growing areas of Mahananeriya (Dry Zone), Ibbagamuwa (Intermediate Zone) and Alawwa (Wet Zone) were estimated to be 14\%, 28\% and18\%, respectively, of the total area of each region. The extent of rainfed paddy fields out of the total extent of paddy fields were $7 \%$ in Mahananeriya, 36\% in Ibbagamuwa and 80\% in Alawwa.

Soil $\mathrm{pH}$ varied from 3.8 to 8.0 in Mahananeriya, from 3.8 to 7.2 in Ibbagamuwa and 3.2 to 5.0 in Alawwa ASC regions. The percentage land extent of rainfed paddy fields according to soil $\mathrm{pH}$ in Mahananeriya, Ibbagamuwa and Alawwa ASC regions are shown in Table 1. The soil $\mathrm{pH}$ in all rainfed paddy areas of Alawwa (WZ) was far below the optimum level (6-7) for paddy cultivation. With the high rainfall, majority of the basic cations including $\mathrm{K}$ could be leached out and thus the soil would become acidic (Reuss, 1980., Kumaragamage et. al., 1999). This may be the major reason for low $\mathrm{pH}$ recorded in Alawwa region where rainfall is high.

Table 1. Percentage land extent of rainfed paddy fields according to soil $\mathrm{pH}(1: 2.5)$ in Mahananeriya, Ibbagamuwa and Alawwa ASC regions

\begin{tabular}{cccc}
\hline Soil pH (1:2.5) & \multicolumn{3}{c}{ Percentage land extent } \\
\cline { 2 - 4 } & Mahananeriya (DZ) & Ibbagamuwa (IZ) & Alawwa (WZ) \\
\hline$<4$ & - & 1 & 74 \\
$4-5$ & 37 & 39 & 26 \\
$5-6$ & 57 & 45 & - \\
$6-7$ & 5 & 15 & - \\
$7-8$ & 1 & 0.1 & - \\
\hline
\end{tabular}

The EC levels were low in all three areas and the maximum EC values of Mahananeriya, Ibbagamuwa and Alawwa were $0.5,0.75$ and $0.25 \mathrm{dS} \mathrm{m}^{-1}$, respectively. The percentage land extent of rainfed paddy fields according to the EC in Mahananeriya, Ibbagamuwa and Alawwa ASC regions are shown in Table 2. More than $84 \%$ of the rainfed paddy lands in all three regions are highly suitable for rice cultivation in terms of EC levels. 
Table 2. Percentage land extent of rainfed paddy fields according to EC (1:5) $\mathrm{dS} / \mathrm{m}$ in Mahananeriya, Ibbagamuwa and Alawwa ASC regions

\begin{tabular}{lccc}
\hline EC (1:5) & Percentage land extent & & \\
\cline { 2 - 4 } dS/m & Mahananeriya (DZ) & Ibbagamuwa (IZ) & Alawwa (WZ) \\
\hline$<0.15$ & 84 & 87 & 99.8 \\
$0.15-0.4$ & 13 & 13 & 0.2 \\
$0.4-0.8$ & 3 & 0.1 & - \\
\hline
\end{tabular}

The available soil-P levels varied from 3.6 to $30.0 \mathrm{mg} \mathrm{P} / \mathrm{kg}$ in Mahananeriya, from 3.0 to $13.0 \mathrm{mg} \mathrm{P} / \mathrm{kg}$ in Ibbagamuwa and 3.7 to $34.0 \mathrm{mg}$ P/kg in Alawwa ASC regions. Percentage land extent of rainfed paddy fields according to soil available $\mathrm{P}$ content $(\mathrm{mg} \mathrm{P} / \mathrm{kg}$ ) in Mahananeriya, Ibbagamuwa and Alawwa ASC regions are shown in Table 3. Most of the area in all three regions had more than $5 \mathrm{mg} \mathrm{P} / \mathrm{kg}$, which falls within the optimum level of available-P for rice (5-10 mg P/kg). Phosporous is accumilated in the soil when there is no enough water for plants to absorb P (Sirisena et al., 2009). This may be a reason for $91 \%$ area in Mahananeriya in the Dry Zone to have more than the optimum level of available of soil-P. There is a tendency to fix $\mathrm{P}$ with $\mathrm{Al}$ and $\mathrm{Fe}$ in the wet zone areas (Wickramasinghe $e t$ al., 2009). Accordingly, the Intermediate and Wet zone areas in the study sites reported relatively low available $\mathrm{P}$ in the rainfed paddy soils.

Table 3. Percentage land extent of rainfed paddy fields according to soil available $P$ content (mg P/kg) in Mahananeriya, Ibbagamuwa and Alawwa ASC regions

\begin{tabular}{cccc}
\hline soil available $\mathbf{P}$ & \multicolumn{3}{c}{ Percentage land extent } \\
\cline { 2 - 4 } $\begin{array}{c}\text { content (mg } \\
\text { P/kg) }\end{array}$ & Mahananeriya (DZ) & Ibbagamuwa (IZ) & Alawwa (WZ) \\
\hline$<5$ & 1 & 6 & 2 \\
$5-10$ & 8 & 93 & 88 \\
$>10$ & 91 & 1 & 10 \\
\hline
\end{tabular}

The exchangeable-K levels varied from 7.2 to $433.0 \mathrm{mg} \mathrm{K} / \mathrm{kg}$ in Mahananeriya, from 10.5 to $253.0 \mathrm{mg} \mathrm{K} / \mathrm{kg}$ in Ibbagamuwa and 0.2 to $70.0 \mathrm{mg} \mathrm{K} / \mathrm{kg}$ in Alawwa ASC regions showing higher variations within regions. The percentage land extent of rainfed paddy fields according to the exchangeable-K content $(\mathrm{mg} \mathrm{K} / \mathrm{kg})$ in Mahananeriya, Ibbagamuwa and Alawwa ASC regions are shown in Table 4. In the Alawwa ASC region, 93\% of the paddy lands had low exchangable $\mathrm{K}$ content (less than $40 \mathrm{mg} \mathrm{K} / \mathrm{kg}$ ) compared to the optimum level (80-160 mg K/kg) for rice cultivation. As Alawwa recevied more rain than other two regions, leaching of $\mathrm{K}$ through rainwater may be a reason for low level of $\mathrm{K}$ in Alawwa.

Table 4. Percentage land extent of rainfed paddy fields according to Exchangable $\mathrm{K}$ content $(\mathrm{mg} / \mathrm{kg})$ in Mahananeriya, Ibbagamuwa and Alawwa ASC regions

\begin{tabular}{cccc}
\hline \multirow{2}{*}{$\begin{array}{c}\text { Exchangable K } \\
\text { content (mg }\end{array}$} & \multicolumn{3}{c}{ Percentage land extent } \\
\cline { 2 - 4 } K/kg) & Mahananeriya (DZ) & Ibbagamuwa (IZ) & Alawwa (WZ) \\
\hline$<40$ & 1 & 31 & 93 \\
$40-80$ & 40 & 55 & 7 \\
$80-160$ & 21 & 12 & - \\
$>160$ & 38 & 2 & - \\
\hline
\end{tabular}


Fig. 2 and 3 illustrate the available soil-P, exchangeable soil-K, and $\mathrm{pH}$ and EC of soils in the three selected ASC areas.
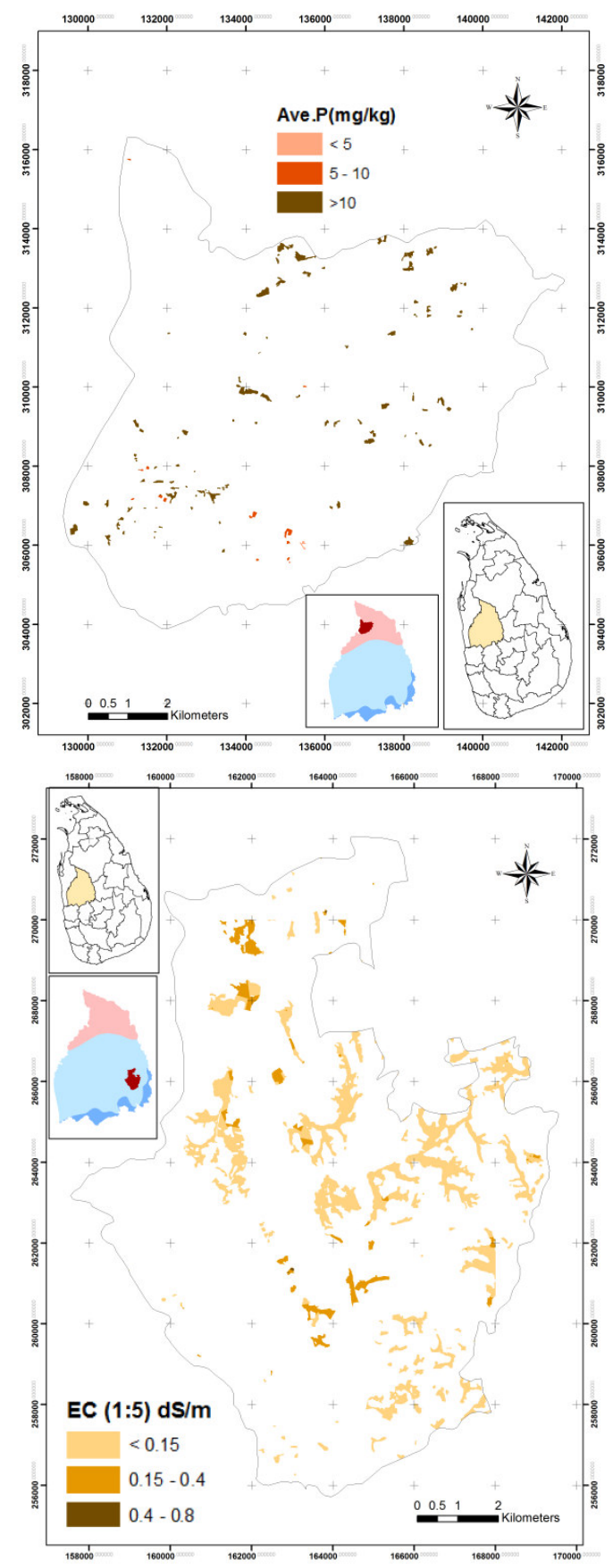

Fig. 2. Maps of the spatial variability of available soil-P in Mahananeriya and Electrical Conductivity of paddy soils in Ibbagamuwa ASC areas 

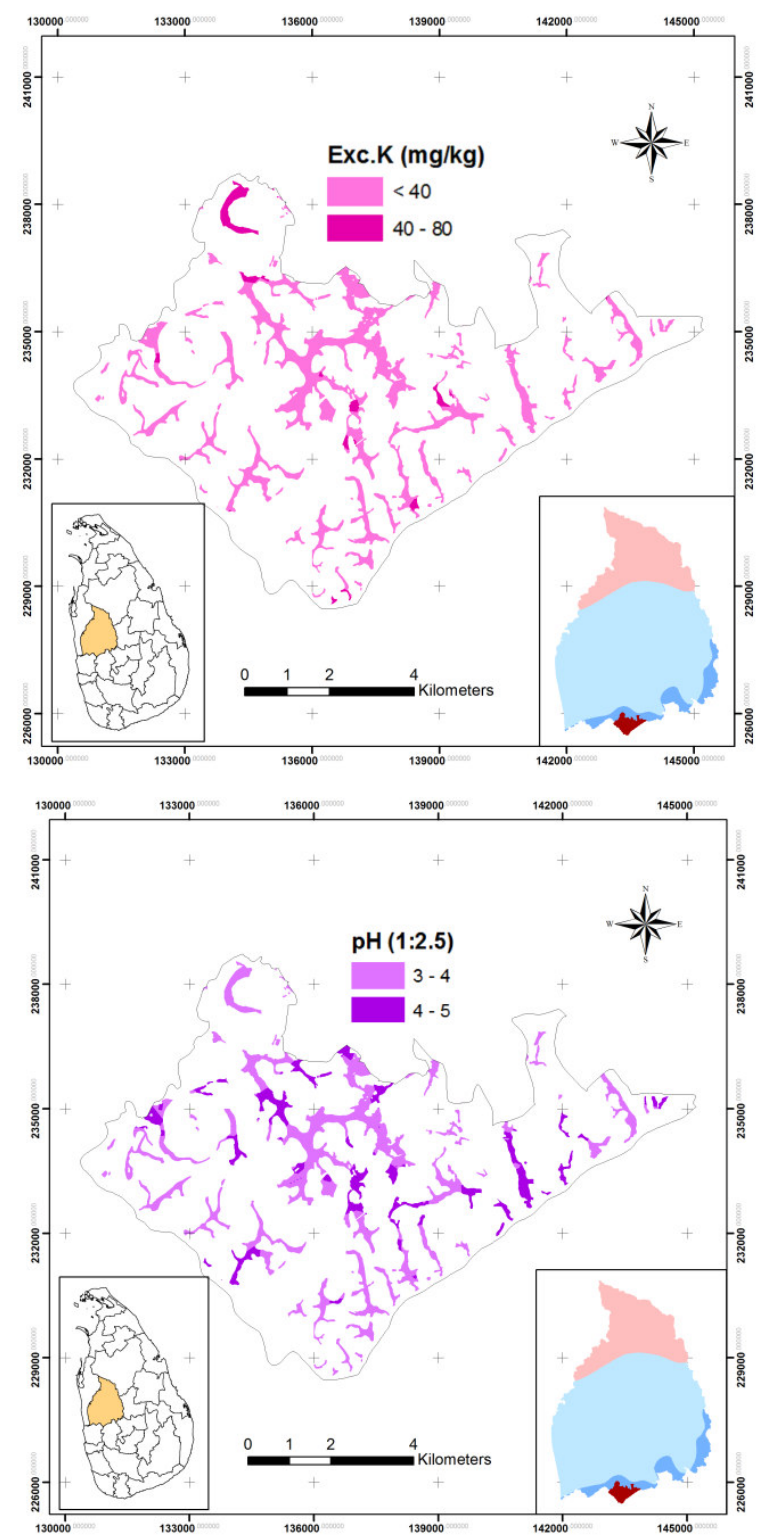

Fig. 3. Maps of the spatial variability of exchangeable soil-K and soil pH of paddy soils in Alawwa ASC area

The map of soil suitability in terms of soil chemical properties shows the marginally suitable, moderately suitable, suitable and highly suitable areas for rainfed rice cultivation in Mahananeriya (Fig. 4), Ibbagamuwa (Fig. 5) and Alawwa (Fig. 6). About $79 \%$ of land extent in Alawwa area is in the marginally suitable class mainly due to the low exchangable soil-K and soil $\mathrm{pH}$ (Table 5). 
Table 5. Percentage land extent of rainfed paddy fields according to the suitability of rice cultivation in Mahananeriya, Ibbagamuwa and Alawwa ASC regions

\begin{tabular}{lccc}
\hline \multirow{2}{*}{ Soil Suitability } & \multicolumn{3}{c}{ Percentage land extent } \\
\cline { 2 - 4 } & Mahananeriya (DZ) & Ibbagamuwa (IZ) & Alawwa (WZ) \\
\hline Marginally Suitable & 3 & 13 & 79 \\
Moderately Suitable & 65 & 44 & 21 \\
Suitable & 29 & 29 & - \\
Highly Suitable & 3 & 13 & - \\
\hline
\end{tabular}

In all three study regions, soils are mainly sandy loam in texture. Rainfall variation may be the primary factor that changes soil chemical properties among the three regions. Therefore, dry areas have high levels of $\mathrm{K}$ in comparison to wet areas. Further, the soil $\mathrm{pH}$ is high in dry areas than that of wet areas. Therefore, all three regions should be considered separately in terms of soil chemical fertility to improve rice production in rainfed areas in the Kurunegala District of Sri Lanka even if all three regions cultivate rice under rainfed system.

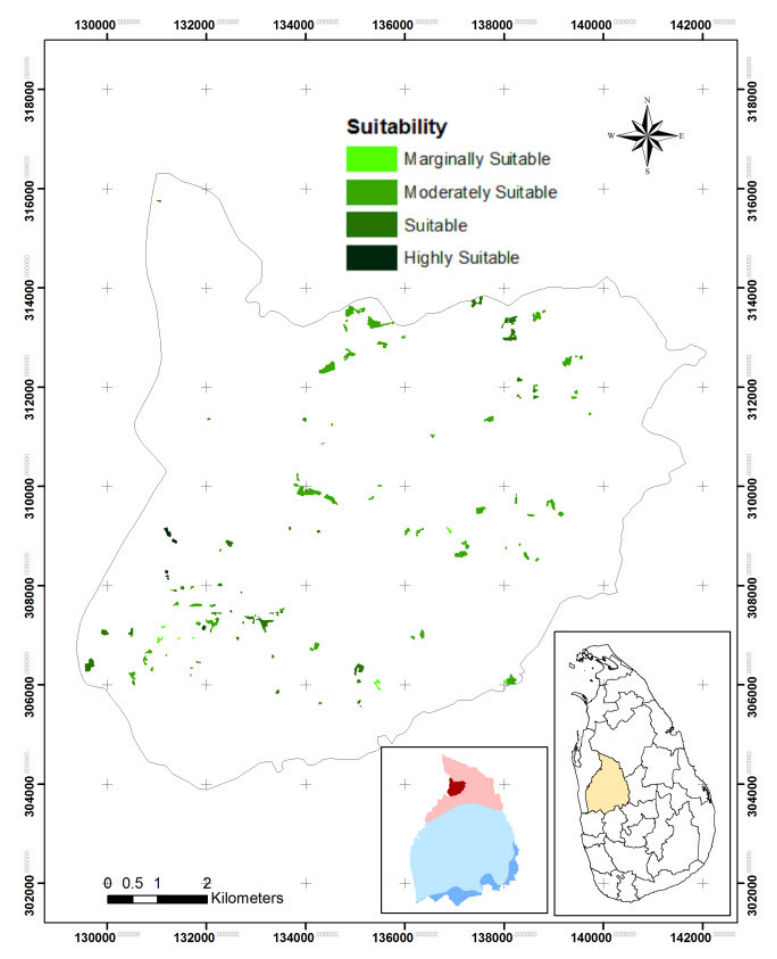

Fig. 4. Map of soil chemical suitability for rice cultivation in Mahananeriya ASC region 


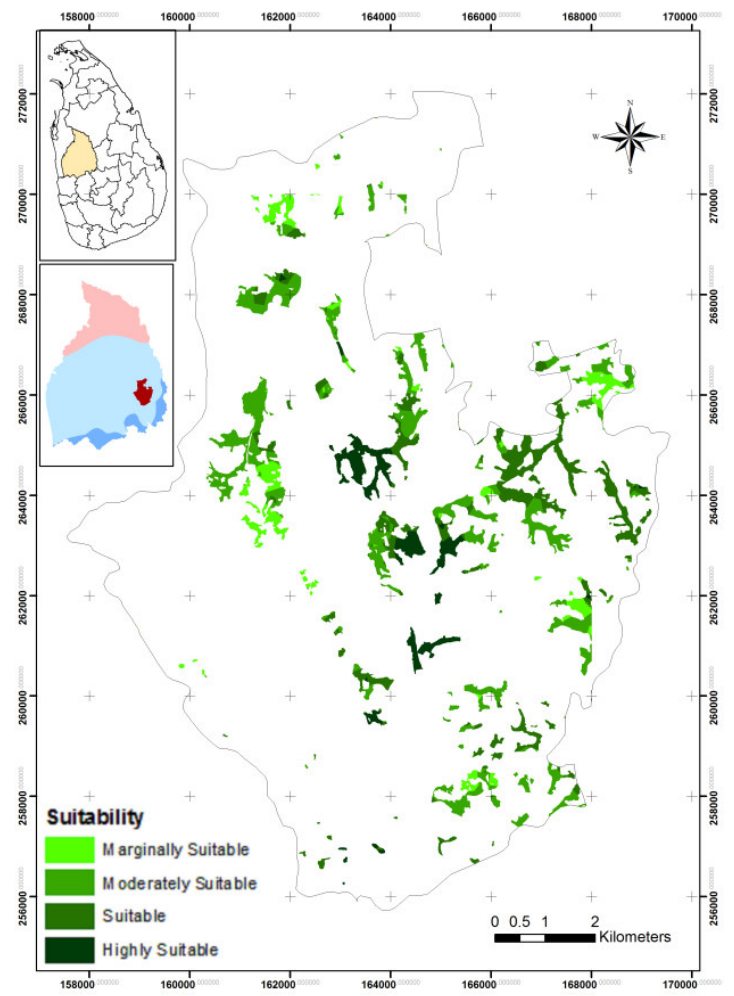

Fig. 5. Map of soil chemical suitability for rice cultivation in Ibbagamuwa ASC region

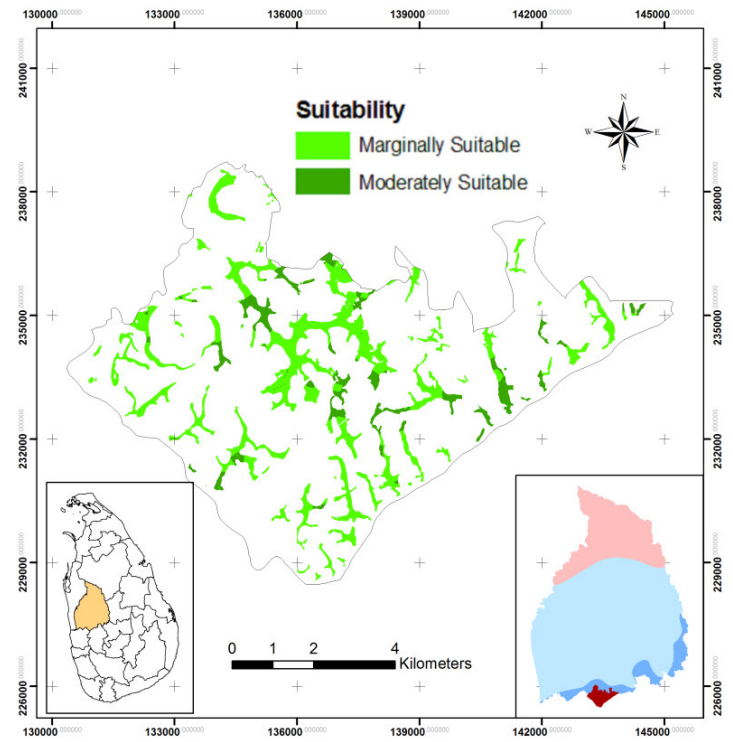

Fig. 6. Map of soil chemical suitability for rice cultivation in Alawwa ASC region 


\section{CONCLUSION}

Chemical properties of rainfed low land paddy fields of Kurunegala district are highly variable. Though the available soil-P and soil-EC values are optimum for rice production in the rainfed paddy fields in all three ASCs, their potential productivity cannot be obtained due to the variability of soil $\mathrm{pH}$ and exchangeable soil-K contents. Therefore, blanket recommendations of remedial measures cannot be introduced to improve the productivity of rainfed paddy fields in all three regions studied. Hence, site specific remedial measures should be used to solve problems created due to different soil chemical properties in the study regions.

\section{ACKNOWLEDGEMENT}

Authors wish to thank the Sri Lanka Council for Agriculture Research Policy (SL-CARP) and the Department of Agriculture for providing funds to carry out this research successfully. Authors also wish to thank Mr. D.N. Sirisena, the Deputy Director (Research and Development) of the Rice Research and Development Institute, Sri Lanka for his valuable encouragements and to Ms. A.P.N. Nandasena and Ms. J.M.D. Jayasinghe (Research Assistants) for their support during the data collection and analysis.

\section{REFERENCES}

Abeysiriwardene, D.S.De Z. and Sandanayake, S. (2000). Future rice research as directed by trends in cultivated extent and yield of rice during the recent past. Proceedings of the Annual Symposium of the Department of Agriculture, 2, 371 - 381,

Bandara,W.M.J, Kumaragamage, D. Wickramasinghe,D.B. and Weerawarna, S.B.A. (2005). Site specific nutrient management strategy to increase rice yields in Low Country Intermediate Zone. J. Soil Sci. Soc, of Sri Lanka, 17, 32 - 43

CBSL (2010). Annual Paddy Reports. Department of Census and Statistics, Central Bank of Sri Lanka Colombo, Sri Lanka.

DOA (1997). Soil test based fertilizer recommendation, Department of Agriculture, Peradeniya.

Kumaragamage, D., Nayakakorala, H.B. and VidanaArachchi, L.P. (1999). Risk and Limitations of Wet zone soils In: Mapa R.B., Somasiri, S. and Nagaraja, S. (Eds.) Soils of the Wet zone of Sri Lanka. Morphology, Characterization and Classification. pp 139-159. Special Publication No 1. Soil Science Society of Sri Lanka. SurvodayaVishva Lekha.

Lathiff, M.A. (2007). Electrical Conductivity. In:Dharmakeerthi, R.S., Indraratne, S.P. and Kumaragamage D. (Eds), Mannual of Soil Sampling and Analysis, pp 51-53. Soil Science Society of Sri Lanka.

Punyawardana, B.V.R., Bandara, T.M.J., Munasinghe, M.A.K., Banda N.J. and Pushpakumara, S.M.V. (2003). Agro-ecological regions of Sri Lanka. Natural Resources Management Center, Department of Agriculture, Peradeniya, Sri Lanka. 
Reuss, J.O. (1980). Simulation of soil nutrient losses resulting from rainfall acidity. Ecological Modelling, 11, 15 - 38.

Sirisena D.N, Rathnayake, W.M.U.K. and Bandara W.M.J. (2010). Availability and spatial variability of plant nutrients in paddy fields of wilgoda irrigation scheme in Kurunegala In: Evans, A.; Jinapala, K. (Eds.). Proceedings of the National Conference on Water, Food Security and Climate Change in Sri Lanka, BMICH, Colombo, Sri Lanka, 9-11 June 2009. Vol.2: Water quality, environment and climate change. Colombo, Sri Lanka: pp 61-68, International Water Management Institute.

Wickramasinghe, W.M.A.D.B., Sirisena, D.N., Bandara, W.M.J. and Wijewardena. J.D.H. (2009). Response of rice to application of phosphorus in Sri Lankan soils.In:Kumaragamage, D., Satyanarayana, T., Harmandeep-Singh and Majumdar, K (Eds). Use of phosphorus and potassium fertilizers in Sri Lankan agriculture. pp 197-200, International Plant Nutrition Institute (IPNI), Gurgaon, Haryana, India. 